Наносистели, нанолатеріали, нанотехнології Nanosistemi, Nanomateriali, Nanotehnologii 2020 , т. 18, № 4, сс. 929-937
(C) 2020 ІМФ (Інститут металофізики ім. Г. В. Курдюмова НАН України) Надруковано в Україні. Фотокопіювання дозволено тільки відповідно до ліцензії

PACS numbers: 61.05.cp, 62.23.St, 68.37.-d, 78.67.Rb, 81.07.Lk, 81.16.Pr, 81.70.Pg

\title{
Influence of CuO Nanoparticles on the Structure, Thermal, Physical, and Mechanical Properties of MgO-NiO Nanoparticles
}

\author{
Aseel Hadi \\ University of Babylon, \\ College of Materials Engineering, \\ Department of Ceramic and Building Materials, \\ P.O. Box 4, Hilla, Babylon, Iraq
}

In this paper, the structure, thermal, physical, and mechanical properties of magnesium oxide $(\mathrm{MgO})$-nickel oxide $(\mathrm{NiO}) /$ copper oxide $(\mathrm{CuO})$ nanostructure are studied for renewable energy applications. The $\mathrm{MgO}-\mathrm{NiO}$ compound is synthesized with concentration of 80 wt. \% $\mathrm{MgO}$ nanoparticles and 20 wt.\% $\mathrm{NiO}$ nanoparticles; then, $\mathrm{CuO}$ nanoparticles are added to $\mathrm{MgO}-\mathrm{NiO}$ with different weight percentage (1,2 and 3). The samples are mixed, and then pressed at $225 \mathrm{MPa}$, and sintered at $1250^{\circ} \mathrm{C}$ for 1 hour. The effect of $\mathrm{CuO}$ promoter on the thermal, structure, physical, and mechanical properties of $\mathrm{MgO}-\mathrm{NiO}$ nanoparticles is investigated by means of x-ray diffraction, optical microscope, DTA, apparent density, apparent porosity, water absorption, and $H V$ microhardness. The experimental results of XRD show formation the $\mathrm{MgNiO}_{2}$ compound. It is found the increase in apparent density and $H V$ microhardness, while the apparent porosity and water absorption decrease with raise in concentration of $\mathrm{CuO}$ nanoparticles. The results indicate that the $\mathrm{MgO}-\mathrm{NiO} / \mathrm{CuO}$ nanostructure may be used for different applications such as solar cell, integrated circuits, transistors and other modern applications.

У даній роботі розглядаються структури, теплові, фізичні та механічні властивості наноструктури «оксид Магнію (MgO)-оксид Ніклю (NiO)/оксид Купруму (CuO)» для застосувань у відновлюваних джерелах енергії. Сполука $\mathrm{MgO}-\mathrm{NiO}$ синтезується з концентрацією 80 ваг.\% наночастинок $\mathrm{MgO}$ та 20 ваг.\% наночастинок $\mathrm{NiO}$; наночастинки $\mathrm{CuO}$ потім додаються в $\mathrm{MgO}-\mathrm{NiO}$ з різними ваговими відсотками (1, 2 і 3). Зразки змішуються, а потім стискуються за $225 \mathrm{MПа} \mathrm{та} \mathrm{спікаються} \mathrm{за} 1250^{\circ} \mathrm{C}$ протягом 1 години. Вплив промотера $\mathrm{CuO}$ на теплові, структурні, фізичні та механічні властивості наночастинок $\mathrm{MgO}-\mathrm{NiO}$ досліджено за допомогою рентгенівської дифракції, оптичного мікроскопа, ДТА, міряння видимої густини, видимої пористости, водопоглинення та мікротвердости за Віккерсом $H V$. Експериментальні результати рентґенівської дифракції 
показують формування сполуки $\mathrm{MgNiO}_{2}$. Виявлено збільшення видимої густини та мікротвердости $H V$, в той час як видима пористість та поглинання води зменшуються 3 підвищенням концентрації наночастинок $\mathrm{CuO}$. Результати показують, що наноструктуру $\mathrm{MgO}-\mathrm{NiO} / \mathrm{CuO}$ можна використовувати для різних застосувань, таких як сонячні елементи, інтегральні схеми, транзистори та інші сучасні застосування.

Key words: magnesium oxide, magnesium-nickel oxide, copper oxide, apparent density, differential thermal analysis, apparent porosity.

Ключові слова: оксид Магнію, оксид Магнію-Ніклю, оксид Купруму, видима густина, диференційна термічна аналіза, видима пористість.

(Received 25 March, 2020; in final version, 1 April, 2020)

\section{INTRODUCTION}

Nanoparticles are dissimilar from bulk materials because of their exclusive chemical, electronic, and optical properties. They have very attractive and practical properties, which can be used for a diversity of non- structural and structural applications. Throughout the past decade, the nanooxides have acquired greatly concentration due to their broad potential technical applications in numerous fields like conversions of solar energy, as a heterogeneous catalysts and gas sensors [1]. One of the greatest normally using metal oxides transition for a broad range of field is $\mathrm{NiO}$. $\mathrm{NiO}$ is a NaCl-type antiferromagnetic oxide semiconductor. Uniform sized and well-dispersed nickel oxide nanoparticles like a type of useful material has concerned wide interests owing to its novel mechanical [2], optical, magnetic, electronic [3], and thermal properties and potential application in battery electrodes, catalyst, electrochemical films, gas sensors, and photoelectronic devices. In these fields, it is yet wanted to manufacture ultrafine powders with high quality to obtain properties in their morphology, dimension, magnetic properties, optical characterizations, etc., which are the majority basic factors, which determine the features of the final products [2]. Magnesium oxide ( $\mathrm{MgO})$ has exceptional properties like chemical inertness and electric insulation. $\mathrm{MgO}$ has numerous advantages in applications such as microwave communication, protective layers, optoelectronic devices [4] and materials of refractory [5, 6]. Copper oxide is a transition metal oxide and has a monoclinic structure. Copper oxide compounds are industrially famous materials used in applications like electronic materials, solar energy materials, magnetic media, gas sensor, catalyst, and batteries [7]. In this paper, the preparation of $\mathrm{MgO}-$ $\mathrm{NiO} / \mathrm{CuO}$ nanostructure and studying their structure, thermal, physical and mechanical properties to use it for modern industries and electronics applications. 


\section{MATERIALS AND METHODS}

In this paper, samples of $\mathrm{MgO}, \mathrm{NiO}$ and $\mathrm{CuO}$ nanoparticles were fabricated by using powder metallurgy, $\mathrm{MgO}$ (NanoShel USA company, particle size $50 \mathrm{~nm}$ and high purity $99.9 \%$ ), $\mathrm{NiO}$ (NanoShel USA company, particle size range $(15-35 \mathrm{~nm}$ ) with purity $99.5 \%$ ) and $\mathrm{CuO}$ (US Research Nanomaterials, Inc., USA, particle size $25-55 \mathrm{~nm}$ purity with
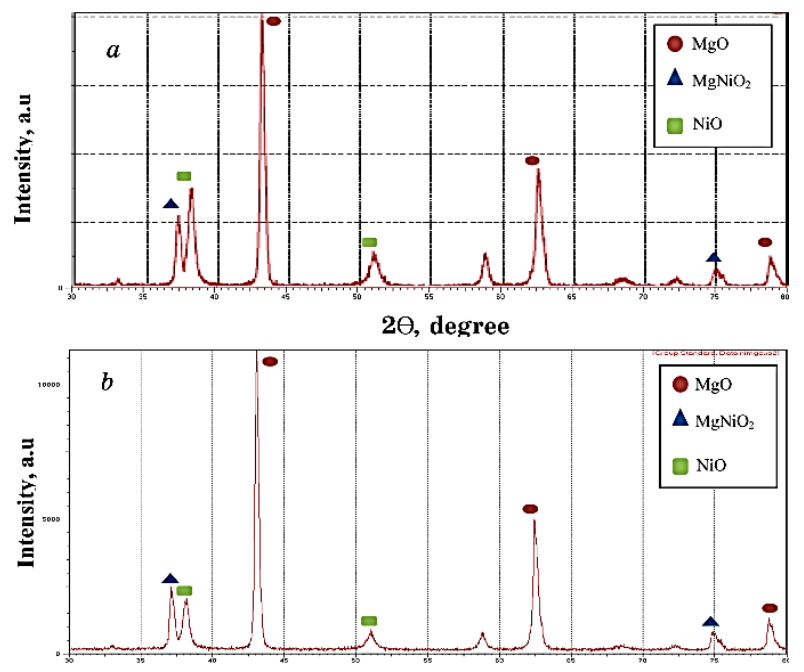

$2 \Theta$, degree

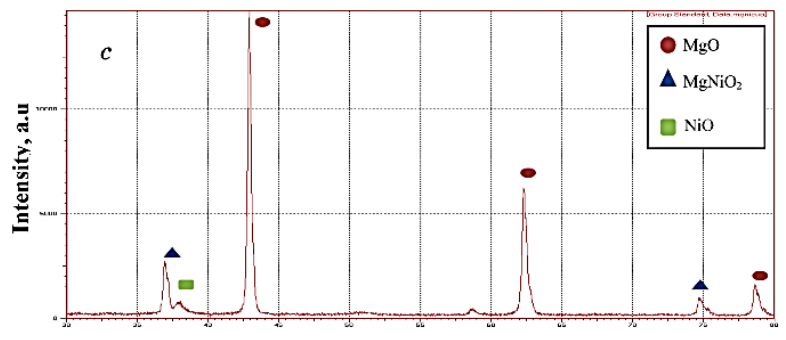

$2 \theta$, degree

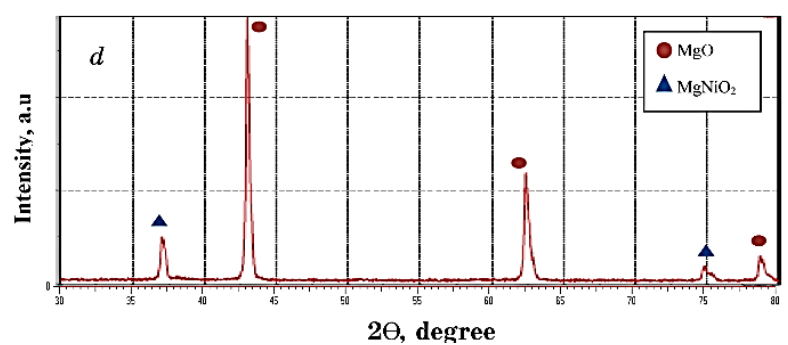

Fig. 1. XRD of $\mathrm{MgO}-\mathrm{NiO}$ nanocompounds at: (a) 0 wt. $\% \mathrm{CuO}$; (b) 1 wt. $\% \mathrm{CuO}$; (c) 2 wt. $\% \mathrm{CuO}$; (d) 3 wt. $\% \mathrm{CuO}$. 
99.5\% ). The $\mathrm{MgO}-\mathrm{NiO}$ nanoparticles were prepared with concentration 80 wt. $\% \mathrm{MgO}$ and 20 wt. $\% \mathrm{NiO}, \mathrm{CuO}$ nanoparticles added to $\mathrm{MgO}$, $\mathrm{NiO}$ at $(0,1,2,3)$ wt. $\%$. The mixtures mixed in electric mixer for $(6$ hrs) then the samples pressed at $225 \mathrm{MPa}$ with $12 \mathrm{~mm}$ diameter. They sintered at $1250^{\circ} \mathrm{C}$ with heating rate $5^{\circ} \mathrm{C} / \mathrm{min}$.

The structural, thermal, physical and mechanical properties were
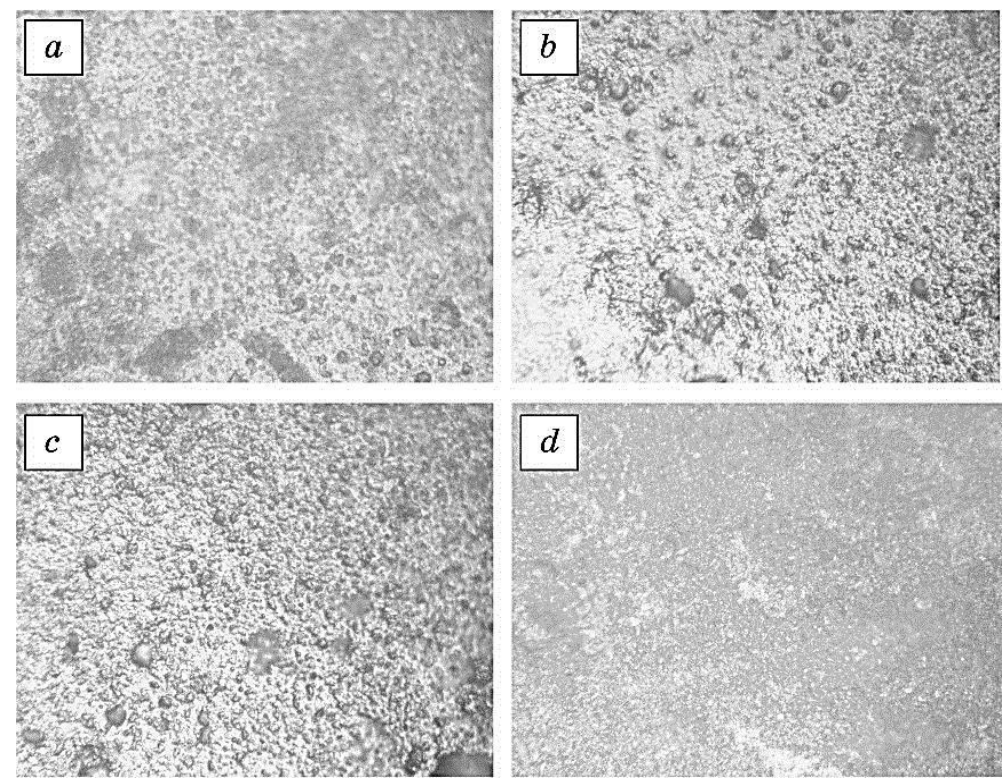

Fig. 2. Microscopy images of $\mathrm{MgO}-\mathrm{NiO}-\mathrm{CuO}$ at: $(a) 0$ wt.\% $\mathrm{CuO}$; (b) 1 wt.\% $\mathrm{CuO} ;(c) 2$ wt. $\% \mathrm{CuO}$; (d) 3 wt. $\% \mathrm{CuO}$.

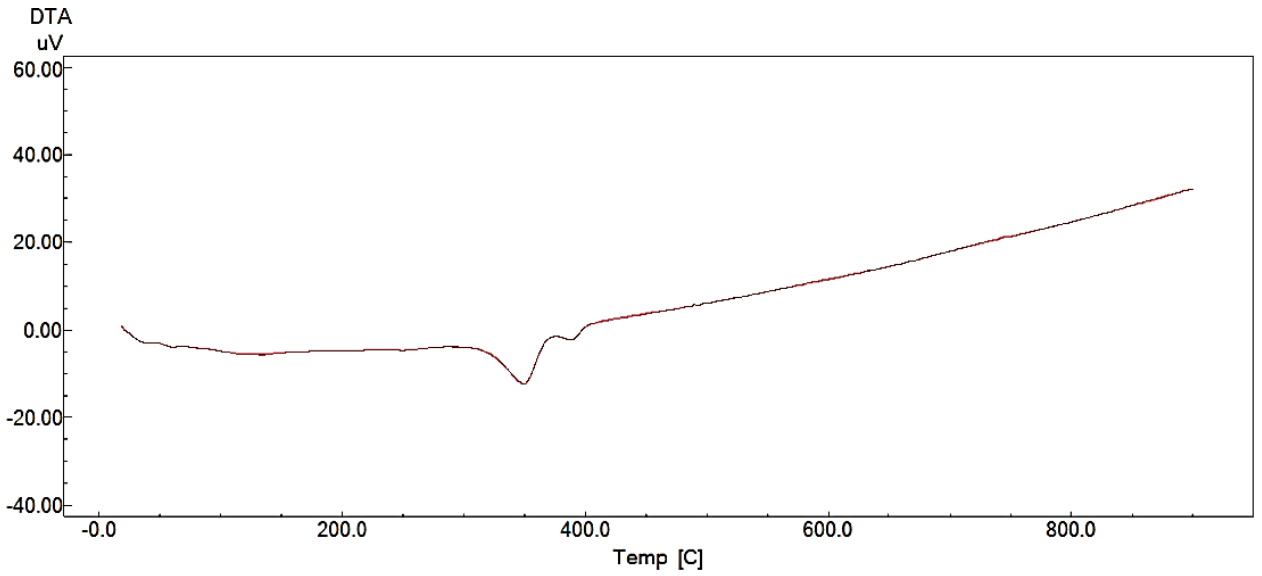

Fig. 3. DTA of MgO nanoparticles. 
studied. X-ray diffraction and optical microscope, differential thermal analysis, apparent density, apparent porosity, water absorption, $H V$ microhardness were studied. The characterizations (apparent density, apparent porosity, water absorption) were calculated by using ASTM C373-88 [8].

\section{RESULTS AND DISCUSSION}

Figure 1 shows $\mathrm{x}$-ray diffraction of $\mathrm{MgO}, \mathrm{NiO}$ nanocompounds with different concentrations of $\mathrm{CuO}$ nanoparticles. From Figure 1, $a, b$, and $c$ explaining formation compound $\mathrm{MgNiO}_{2}$ from the reaction be-

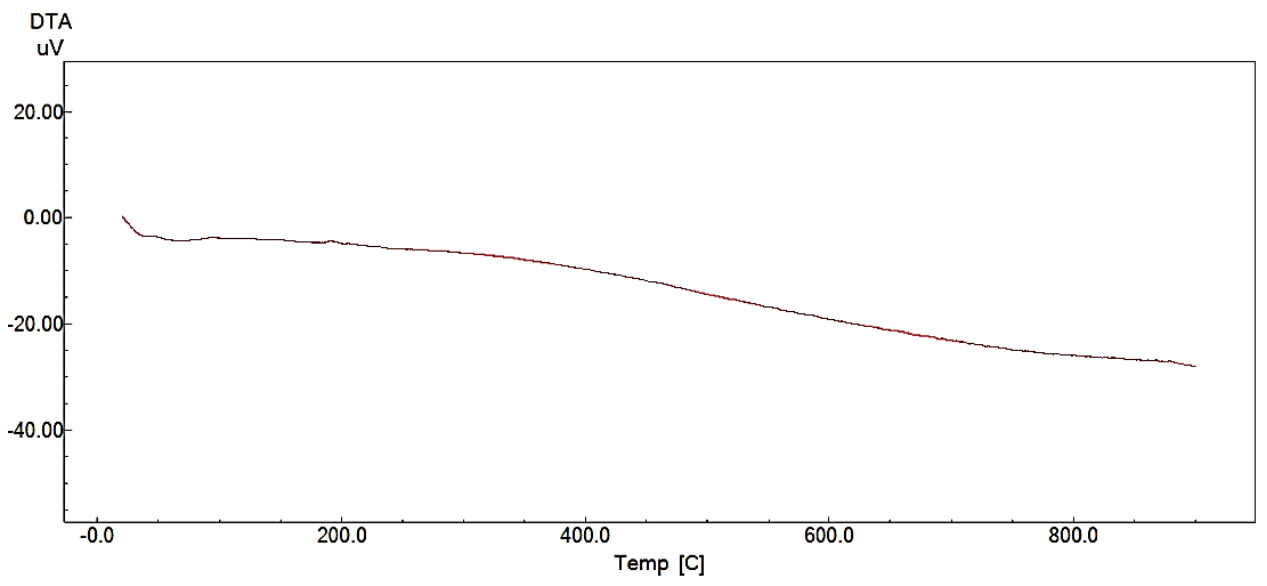

Fig. 4. DTA of NiO nanoparticles.

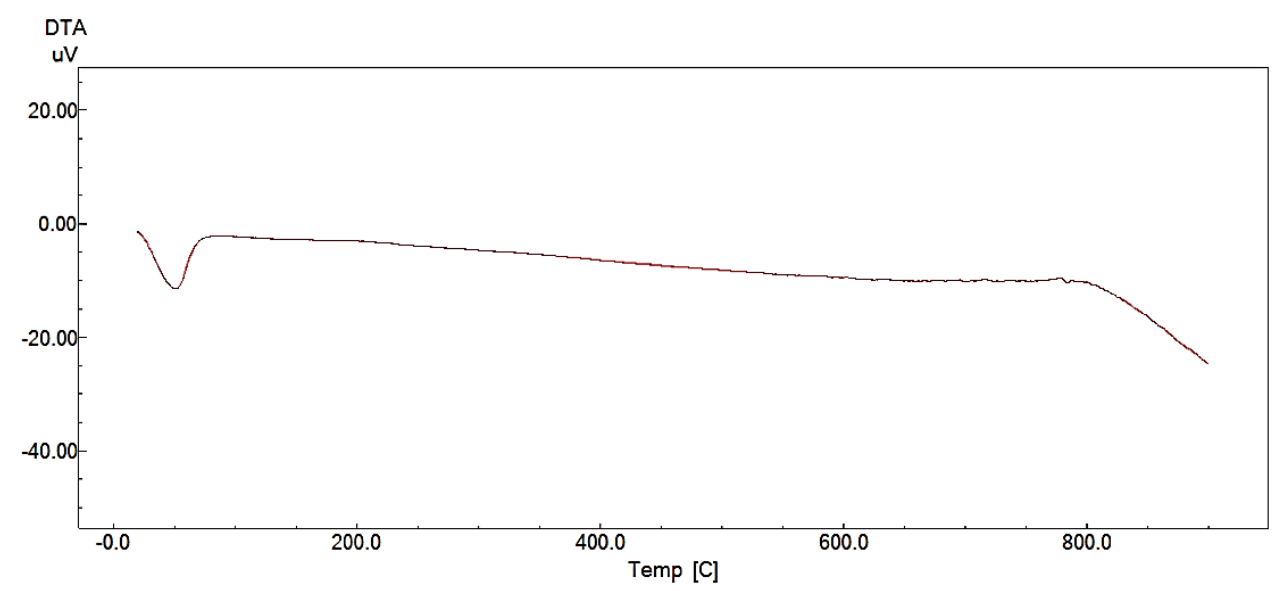

Fig. 5. DTA of CuO nanoparticles. 
tween $\mathrm{MgO}$ and $\mathrm{NiO}$, magnesium nickel oxide $\left(\mathrm{MgNiO}_{2}\right)$ compound was specified due to JCPDS card number 00-024-0712. In addition to find $\mathrm{MgO}$ and $\mathrm{NiO}$, magnesium oxide $(\mathrm{MgO})$ and nickel oxide $(\mathrm{NiO})$ were matched with JCPDS card numbers 00-004-0829 and 04-0835 respectively. This behaviour returned to the oxide amounts, which dissolved in magnesium oxide lattice based largely on the oxides character, addition foreign cations and the conditions of calcinations [9].

Figure 1, $d$ shows formation $\mathrm{MgNiO}_{2}$ compound with availability of

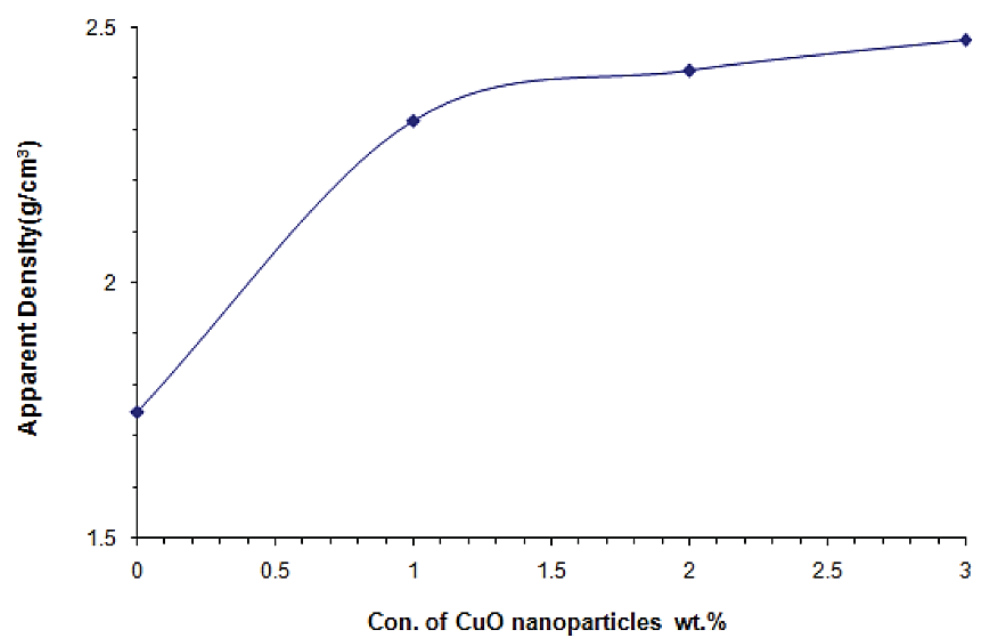

Fig. 6. Relationship between apparent density and $\mathrm{CuO}$ nanoparticles content.

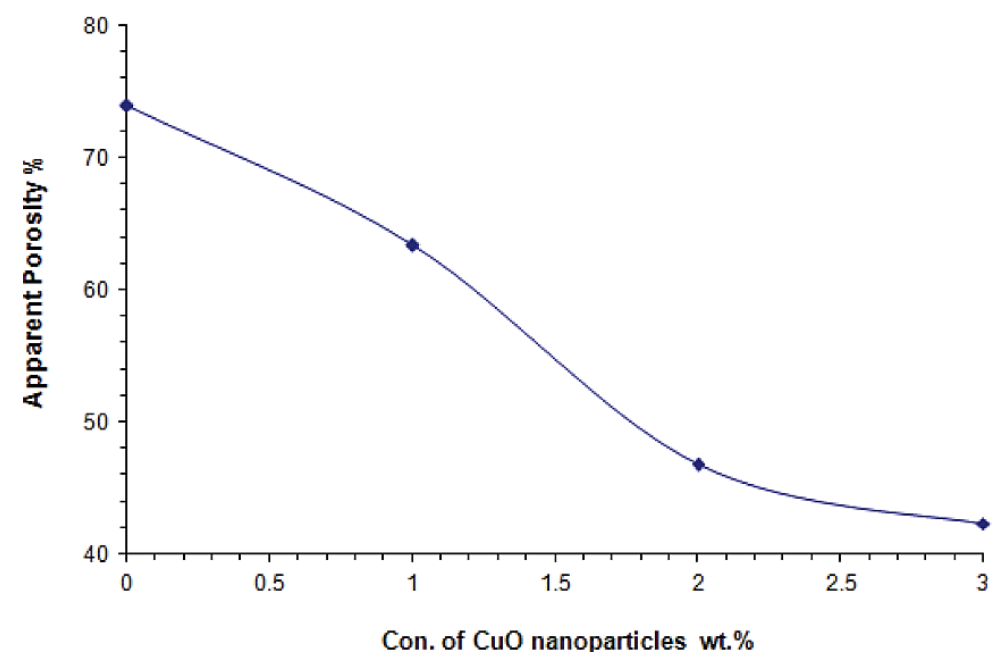

Fig. 7. The variation of apparent porosity and $\mathrm{CuO}$ nanoparticles content. 
$\mathrm{MgO}$. These results agree with the results of researchers [10]. Copper oxide does not appear in XRD due to little addition from it and the XRD apparatus does not fumble the copper oxide.

Figure 2 represents the microscopy images of $\mathrm{MgO}-\mathrm{NiO}-\mathrm{CuO}$ at different weight percentages of $\mathrm{CuO}$ nanoparticles. This figure shows uniform distribution of $(\mathrm{MgO}-\mathrm{NiO}-\mathrm{CuO})$ nanoparticles.

Figure 3 shows DTA of $\mathrm{MgO}$; the first peak shows inorganic evapo-

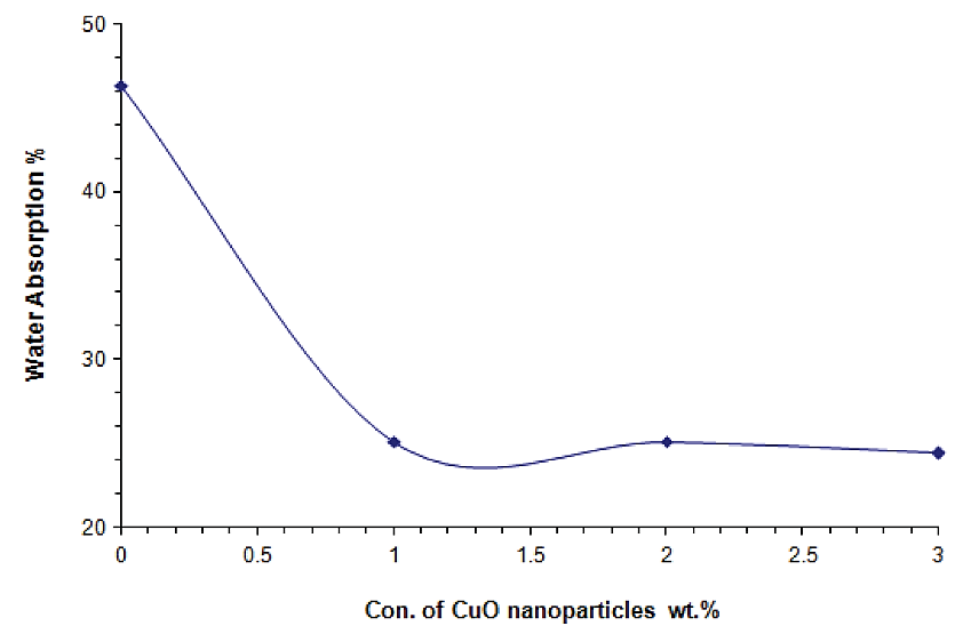

Fig. 8. The relationship between water absorption and $\mathrm{CuO}$ nanoparticles content.

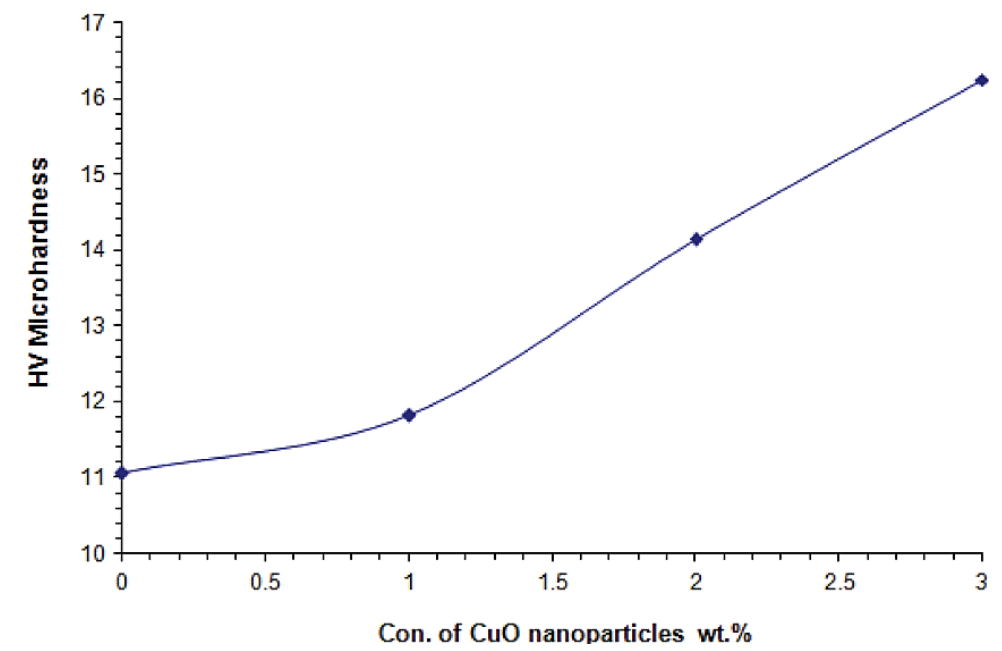

Fig. 9. The variation between Vickers microhardness and different concentrations of $\mathrm{CuO}$ nanoparticles. 
ration at $350^{\circ} \mathrm{C}$ and the second peak explains phase transformation at $380^{\circ} \mathrm{C}$ [11] while Fig. 4 shows no change during heating to $\mathrm{NiO}$ nanoparticles, Fig. 5 explains DTA of $\mathrm{CuO}$ with appearing peak at $50^{\circ} \mathrm{C}$ which meaning moisture evaporation.

Figure 6 shows the relationship between apparent density and different weight percentages of $\mathrm{CuO}$ nanoparticles, this figure explains the increase in apparent density with increase concentrations of $\mathrm{CuO}$ nanoparticles, which may be return to full the spaces among particles by $\mathrm{CuO}$ nanoparticles because elevated catalyst activity [12] and formation $\mathrm{MgNiO}_{2}$ compound.

Figure 7 shows the variations between apparent porosity and concentrations of weight percentages of $\mathrm{CuO}$ nanoparticles. The effect of $\mathrm{CuO}$ nanoparticles weight percentages on water absorption is shown in Fig. 8. From Figures 7 and 8, apparent porosity and water absorption decrease with raise the weight percentages of $\mathrm{CuO}$ nanoparticles. The reducing in apparent porosity/water absorption may be explained by increasing in the apparent density.

Figure 9 explains the variation between Vickers microhardness with $\mathrm{CuO}$ nanoparticles concentrations. Vickers microhardness arises with increase weight percentages of $\mathrm{CuO}$ nanoparticles. This increasing related to increase the compaction and decrease in porosity in addition to formation $\mathrm{MgNiO}_{2}$ compound. In addition, $\mathrm{CuO}$ nanoparticles have different mechanical strengths from their bulk materials [13].

\section{CONCLUSION}

The XRD results of $\mathrm{MgO}-\mathrm{NiO}$ samples with addition various ratios of $\mathrm{CuO}$ nanoparticles shows formation $\mathrm{MgNiO}_{2}$ compound with appears $\mathrm{MgO}$ and $\mathrm{NiO}$ compounds. The thermal properties of $\mathrm{MgO}-\mathrm{NiO} / \mathrm{CuO}$ samples included DTA of $\mathrm{MgO}$, the two peaks of $\mathrm{MgO}$ show at $350^{\circ} \mathrm{C}$ and $380^{\circ} \mathrm{C}$ while shows no change during heating of $\mathrm{NiO}$, DTA of $\mathrm{CuO}$ explains peak at $50^{\circ} \mathrm{C}$. The physical properties of $\mathrm{MgO}-\mathrm{NiO}$ samples, the apparent density increase while apparent porosity and water absorption decrease with raise concentrations of $\mathrm{CuO}$ nanoparticles. The mechanical properties showed that the $\mathrm{HV}$ microhardness of $\mathrm{MgO}-\mathrm{NiO}$ increases with the increase in $\mathrm{CuO}$ nanoparticles concentrations.

\section{REFERENCES}

1. A. Asha Radhakrishnan and B. Baskaran Beena, Indian Journal of Advances in Chemical Science, 2, No. 2: 158 (2014).

2. K. Anandan and V. Rajendran, Nanoscience and Nanotechnology: An International Journal, 2, No. 4: 24 (2012).

3. Burçak Ebin, Journal of Inorganic and Organometallic Polymers and Materials, 28: 2554 (2018). 
4. C. Ye, S. S. Pan, X. M. Teng, and G. H. Li, Journal of Applied Physics, 102: 013520 (2007).

5. Zeyneb Camtakan, Sema (Akyil) Erenturk, and Sabriye (Doyurum) Yusan, En vironmental Progress \& Sustainable Energy, 31, No. 4: 536 (2012).

6. M. Sundrarajan, J. Suresh, and R. Rajiv Gandhi, Digest Journal of Nanomaterials and Biostructures, 7, No. 3: 983 (2012).

7. N. R. Dhineshbabu, V. Rajendran, N. Nithyavathy, and R. Vetumperumal, Appl. Nanosci., 6: 933 (2016).

8. $\quad$ ASTM Standard, 373 (1999).

9 A. M. Salem, M. Mokhtar, and G. A. El-Shobaky, Solid State Ionics, 170: 33 (2004).

10. Nader Setoudeh, Cyrus Zamani, and Mohammad Sajjadnejad, Journal of Ultrafine Grained and Nanostructured Materials, 50, No. 1: 51 (2017).

11. C. H. Ashok, Rao K. Venkateswara, and C. H. Shilpa Chakra, J. Nanomed. Nanotechnol., 6, Iss. 6: (2015). doi: 10.4172/2157-7439.1000329

12. Huei Ruey Ong, Md. Maksudur Rahman Khan, Ridzuan Ramli, Rosli Mohd Yunus, Procedia Chemistry, 16: 623 (2015).

13. Mădălina Elena David, Elena Ramona Biscu, Alina Holban, Monica Cartelle Gestal, Pharmaceuticals, 9, No. 4: 75 (2016). DOI: 10.3390/ph9040075 